\title{
MORPHOLOGICAL CHARACTERIZATION OF THE AFRICAN CATFISH (Clarias gariepinus BURCHELL, 1822) STRAINS INTRODUCED TO INDONESIA
}

\author{
Bambang Iswanto, Imron, Rommy Suprapto, and Huria Marnis
}

Research Institute for Fish Breeding

(Received 9 July 2015; Final revised 2 November 2015; Accepted 10 November 2015)

\begin{abstract}
African catfish (Clarias gariepinus Burchell, 1822) has become a great important species in Indonesian aquaculture. Several strains of the African catfish have been introduced to Indonesia for aquaculture purposes, initiated by Dumbo strain from Taiwan in 1985, followed by Paiton strain from Thailand in 1998, then Egypt strain from Egypt in 2007, Masamo strain from Thailand in 2010 and later Kenya strain from Kenya in 2011. Since its introductions, there were no reports yet on their characterization studies. The present study was conducted to morphologically characterize the strains of African catfish introduced to Indonesia, i.e. Dumbo, Paiton, Egypt, Masamo, and Kenya strains. Morphometric and meristic data obtained were analyzed using Principal Component Analysis. Results of the morphometric characterization in the present study revealed that Dumbo, Paiton, Masamo, and Kenya strains were indistinguishable, while morphometric characteristic of Egypt strain was more or less different from those of the other strains. On the other hand, results of the meristic characterization suggested that meristic characteristics of all strains of the introduced African catfish were not different from each other. Therefore, to keep the genetic purity of those introduced strains, they should be properly maintained in isolated places.
\end{abstract}

KEYWORDS: morphometric, meristic, introduced strains, African catfish Clarias gariepinus

\section{INTRODUCTION}

African catfish (Clarias gariepinus Burchell, 1822) has becomes a great important species in Indonesian aquaculture. Recently, it has extensively cultured throughout Indonesia, mainly in Java, Sumatra, Bali, and Kalimantan. Utilization of the African catfish in Indonesian aquaculture was initiated in 1985 through introduction of the species from Taiwan. Its fast growing performance is well appreciated by fish farmers, led to rapid development of the aquaculture. This species was very popular and locally named as "Dumbo". Unfortunately, due to improper broodstock management practiced by fish farmers subsequently has led to uncontrolled inbreeding, causing its genetic deterioration, reflected by its low growth performance, susceptible to disease infection, lower feed efficiency, higher size variation, higher deformities, etc (Nurhidayat, 2000; Sudarto, 2014, pers.comm.).

The decreasing performances of Dumbo strain promoted the next introductions of the African catfish into Indonesia. In 1998, Charoen Pokphand Group

\# Correspondence: Research Institute for Fish Breeding. Jl. Raya 2 Sukamandi, Subang 41263, West Java, Indonesia. Phone: + (0260) 520500

E-mail: bambang.is031@kkp.go.id introduced an African catfish from Thailand. Upon its arrival in Indonesia, it was divided into two locations, i.e. placed at the hatchery of PT Surya Windu Pertiwi in Paiton, Probolinggo, and placed at the hatchery of PT Central Panganpertiwi in Pabuaran, Subang (Arsana, 2014; pers.comm.). This African catfish was then popular as Paiton or CP strain. Subsequent introduction of the African catfish was carried out from Egypt by West Java Provincial Agency of Fisheries and Marine Affairs in 2007 (Dharsono, 2011, pers.comm.). This strain then was called as Egypt strain. In 2010 PT Matahari Sakti introduced an African catfish from Thailand, and was placed at the hatchery in Mojokerto (Mubin, 2011; pers.comm.). This strain was then popular as Masamo strain. Later, in 2011 Main Center of Freshwater Aquaculture Development Center (FADC) Sukabumi introduced an African catfish collected from Kenya waters and a strain from a Dutch fish company in Kenya (Sunarma, 2012; pers.comm.). The wild type strain was then called as Kenya strain. Besides from Kenya, a Dutch strain has also been introduced into Malang in 1985 from The Netherlands through joint cooperative project between the University of Brawijaya in Malang and the University of Wageningen in The Netherlands (Widodo, 2010; pers.comm.). However, the introduction was for research purposes, 
and the use of this strain in aquaculture activities was restricted.

Based on those anecdotal informations, during 1985-2011, six or seven (two of which were the Dutch strains) strains of the African catfish have been introduced to Indonesia from relatively different sources. In the fish farmer level, recognition of the strains might not be considered as an important thing, and the use of those strains in the field might be mixed each other. Fortunately, pure isolated stocks of those strains has been maintained either by government institutions or fish companies. Since its introductions, those African catfish strains paid a little attention with regard to its characterization studies. There was no report on their characterization, neither for morphological nor genetic aspects. For genetic management, as well as for genetic improvement purposes, recognition of the identity or information of the characteristics of the strains should be an important thing. The present study aimed to morphologically characterize the introduced strains of African catfish in Indonesia.

\section{MATERIALS AND METHODS}

The present morphological study was conducted in the Research Institute for Fish Breeding (RIFB) Sukamandi. The African catfish samples used in the present study included Sangkuriang strain as a Dumbo strain representative, Paiton strain, Egypt strain, Masamo strain and Kenya strain. The Dutch strain was not included, since a study of cytochrome b sequencing was suggested that the Dutch strain was not a pure species of $C$. gariepinus, but rather a hybrid resulted from hybridization between $C$. gariepinus and $C$. anguillaris (Anene \& Gao, 2007). Sangkuriang strain was used as a representation of Dumbo samples since it was considered as the only original Dumbo strain remained, and based on its history (Sunarma, 2004), Sangkuriang strain was actually also a Dumbo strain. On the other hand, the term Dumbo presently is used by fish farmers as a general name of African catfish other than strains having certain name (Sudarto, 2014; pers.comm.). In other words, the term Dumbo tended to be used as general name of African catfish with unclear identities.

The samples number of Sangkuriang strain used in the present study were 34 fish specimens of 1.2$2.9 \mathrm{~kg}$ body weight (Figure 1A). Those fishes were collected from FADC Sukabumi in early 2014. Samples of Paiton strain used were 33 fish specimens of 2.1$3.7 \mathrm{~kg}$ body weight (Figure 1B). Those fishes were collected from the Breeding Model of Clarias Catfish (MPIL $=$ Model Pembenihan Ikan Lele) Mojokerto in 2010, and were the fourth generation of the African catfish strain introduced from Thailand by Charoen Pokphand Group in 1998. Samples of Egypt strain used in the present study were 31 fish specimens of 1.7 $2.7 \mathrm{~kg}$ body weight (Figure 1C). Those fishes were the first generation of the African catfish introduced from Egypt given by Head of West Java Provincial Agency for Fisheries and Marine Affairs in 2011 as a donation. Samples of Masamo strain were 34 fish specimens of 2.3-3.9 kg body weight (Figure 1D). Those fishes were collected in late 2011 from PT Matahari Sakti hatchery in Mojokerto, and were the first generation of the African catfish introduced from Thailand in 2010. Samples of Kenya strain used in the present study were 28 fish specimens of $2.3-3.9 \mathrm{~kg}$ body weight (Figure 1E). Those fishes were the African catfish collection stocks of PT Suri Tani Pemuka in Purwakarta, originated from FADC Sukabumi in 2012, and were the first generation of the African catfish introduced from Kenya by FADC Sukabumi in 2011.

Morphological characterization of the African catfsh strains in the present study were conducted on morphometric and meristic characters of living fish specimens. Those morphometric and meristic characterizations were conducted using standard methods of biometric characterization commonly used in the morphological characterization studies of the African catfish (Agnese et al., 1997; Rognon et al., 1998; Teugels, 1998, 2003; Teugels et al., 1999a, 1999b, 2007; Turan et al., 2005; Hanssens, 2009). Meristic characters were identified based on the count of total number of pectoral fin rays (PEFR), pelvic fin rays (PFR), dorsal fin rays (DFR), and anal fin rays (AFR). While, for morphometric characters, point to point measurements were undertaken, included: standard length (SL), head length (HL), head width (HW), snout length (SNL), interorbital width (IOW), eye diameter (ED), frontal fontanel length (FFL), frontal fontanel width (FFW), occipital process length (OPL), occipital process width (OPW), occipital process to dorsal fin distance (OPDF), predorsal length (PDL), prepectoral length (PPEL), prepelvic length (PPL), preanal length $(\mathrm{PAL})$, anal fin length (AFL), maximum body depth at anus (MBD), caudal peduncle depth (CPD), premaxillary toothplate width (PMTW), premaxillary toothplate length (PMTL), vomerine toothplate width (VMTW) and vomerine toothplate length (VMTL). Those morphometric characters were measured using digital dial caliper of $0.01 \mathrm{~mm}$ precision (KRISBOW, China).

Morphometric and meristic data obtained were analyzed using standard methods of morphometric and meristic data analysis commonly used in characterization studies of Clarias catfish (Agnese et al., 1997; Rognon et al., 1998; Teugels, 1998, 2003; Teugels 

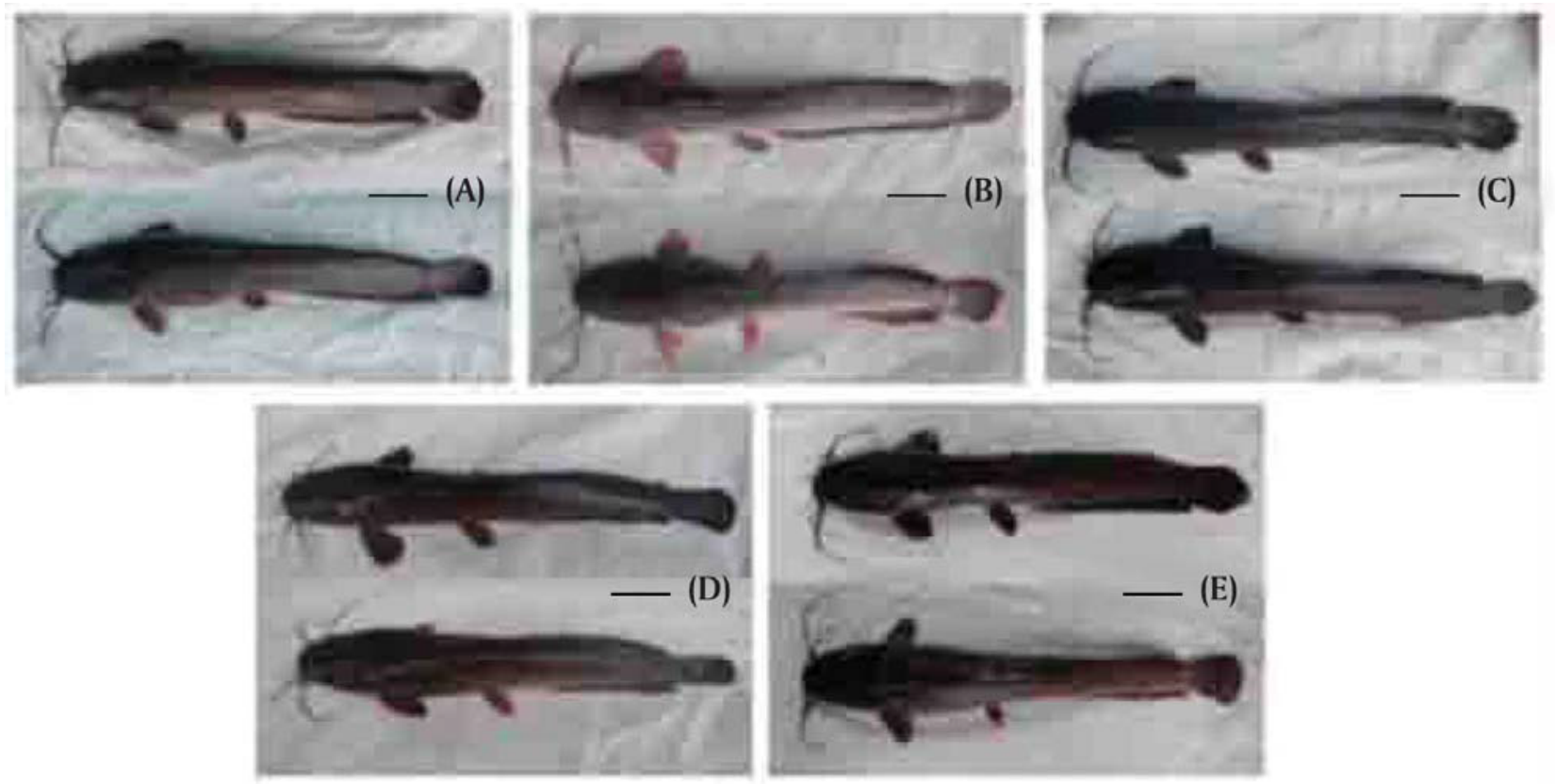

Figure 1. Samples of Dumbo (represented by Sangkuriang strain) (A), Paiton (B), Egypt (C), Masamo (D), and Kenya (E); strains of the African catfish Clarias gariepinus introduced to Indonesia (upper = male, lower $=$ female, bar scales $=10 \mathrm{~cm}$ )

et al., 1999a, 1999b; Sudarto, 2003; Pouyaud et al., 2009). Morphometric data were analyzed using Principal Component Analysis (PCA) based on covariance matrix. For morphometric data analysis, PCA was performed on log-transformed data in order to minimize the effect of size differences of fish samples. The first Principal Component (PC1) considered as size factor was not used in the interpretation of the results, only the remaining Principal Components considered as shape factors used. An independent PCA of untransformed meristic data was run on covariance matrix. Then, Principal Component scores of all samples were plot in pairing with $95 \%$ confidence ellips to characterize the distribution of fish samples. Those data analysis were facilitated by SYSTAT 11 (SYSTAT Software Inc., www.systat.com) computer package software.

\section{RESULTS AND DISCUSSION}

Body colour of living specimens of Dumbo (represented by Sangkuriang strain), Paiton, Egypt, Masamo, and Kenya strains of the African catfish used in the present study showed a slightly variation (Figure 1). Dumbo and Paiton samples had marbled pattern, irregular dark grey blotches in various sizes overlaid a pale brown or grey background on the back and flanks. While, Masamo and Kenya samples had relatively uniform pattern, the back and flanks were dark brown, with several vague small pale dots. On the other hand, Egypt strain had also a uniform pattern with deeply black colour of the back and flanks, without neither blotches nor dots observed. The back and flanks coloration of African catfish in Africa have also been reported to consist of two coloration patterns, i.e. uniform and marbled pattern (Teugels, 1986, 1992; Teugels et al., 2007; Hanssens, 2009).

Results of the measurement of morphometric characters (expressed in the percentage of standard length and head length) and the count of meristic characters of Dumbo, Paiton, Egypt, Masamo, and Kenya strains in the present study were presented in Table 1. Those results indicated that morphometric and meristic characters of Dumbo, Paiton, Egypt, Masamo, and Kenya strains as the African catfish introduced to Indonesia had relatively similar values. There are no striking differences between the values of morphometric and meristic characters of introduced strains of African catfish in Indonesia observed in the present study and those of reported by Teugels (1986) in African waters. Morphometric and meristic characters values observed in the present study were also in accordance with the standard values of morphometric and meristic characters of African catfish C. gariepinus reported in the other literatures (Teugels, 1992; Skelton \& Teugels, 1991; Agnese et al., 1997; Turan et al., 2005; Teugels et al., 2007; Hanssens, 2009; Wiecaszek et al., 2010; FishBase, 2014).

A scatter plot of fish sample scores along the axis of second (PC2) and third (PC3) Principal Component for 20 morphometric characters (excluded standard 
Table 1. Morphometric (in the percentages of standard length and head length) and meristic characteristics of Dumbo, Paiton, Egypt, Masamo, and Kenya strains of the African catfish Clarias gariepinus introduced to Indonesia

\begin{tabular}{|c|c|c|c|c|c|}
\hline \multirow{2}{*}{ Characters" } & \multicolumn{5}{|c|}{ African catfish Clarias gariepinus Strain } \\
\hline & Dumbo & Paiton & Egypt & Masamo & Kenya \\
\hline HL $(\% \mathrm{SL})$ & $\begin{array}{c}26.36-30.27 \\
(28.64 \pm 0.95) \\
\end{array}$ & $\begin{array}{c}25.00-30.63 \\
(28.22 \pm 1.16) \\
\end{array}$ & $\begin{array}{c}23.29-27.60 \\
(25.08 \pm 1.13) \\
\end{array}$ & $\begin{array}{c}27.27-30.96 \\
(28.83 \pm 0.87) \\
\end{array}$ & $\begin{array}{c}25.10-30.11 \\
(26.92 \pm 1.27) \\
\end{array}$ \\
\hline HW $(\% S L)$ & $\begin{array}{c}16.58-19.93 \\
(18.00 \pm 0.91)\end{array}$ & $\begin{array}{c}16.11-19.34 \\
(18.03 \pm 0.72)\end{array}$ & $\begin{array}{c}15.13-17.61 \\
(16.10 \pm 0.66)\end{array}$ & $\begin{array}{c}16.83-19.15 \\
(17.87 \pm 0.53)\end{array}$ & $\begin{array}{r}16.42-18.84 \\
(17.34 \pm 0.66)\end{array}$ \\
\hline SNL $(\% \mathrm{HL})$ & $\begin{array}{c}18.59-25.29 \\
(22.17 \pm 1.71) \\
\end{array}$ & $\begin{array}{c}17.41-26.10 \\
(22.04 \pm 2.06) \\
\end{array}$ & $\begin{array}{c}17.84-26.89 \\
(21.58 \pm 2.01) \\
\end{array}$ & $\begin{array}{c}20.17-30.20 \\
(25.69 \pm 3.56) \\
\end{array}$ & $\begin{array}{c}20.75-25.98 \\
(23.08 \pm 1.40) \\
\end{array}$ \\
\hline IOW $(\% \mathrm{HL})$ & $\begin{array}{c}37.47-43.36 \\
(40.14 \pm 1.60) \\
\end{array}$ & $\begin{array}{c}37.85-42.80 \\
(39.87 \pm 1.09) \\
\end{array}$ & $\begin{array}{c}38.61-45.52 \\
(42.48 \pm 1.30) \\
\end{array}$ & $\begin{array}{c}37.53-43.97 \\
(39.98 \pm 1.62) \\
\end{array}$ & $\begin{array}{r}36.31-42.35 \\
(39.94 \pm 1.39) \\
\end{array}$ \\
\hline ED $(\% \mathrm{HL})$ & $\begin{array}{c}5.26-8.25 \\
(6.90 \pm 0.72)\end{array}$ & $\begin{array}{c}5.44-7.88 \\
(6.25 \pm 0.48)\end{array}$ & $\begin{array}{c}4.46-5.94 \\
(5.18 \pm 0.36)\end{array}$ & $\begin{array}{c}6.12-9.36 \\
(7.30 \pm 0.66)\end{array}$ & $\begin{array}{c}5.05-8.23 \\
(6.39 \pm 0.94)\end{array}$ \\
\hline $\mathrm{OPL}(\% \mathrm{HL})$ & $\begin{array}{c}12.07-19.77 \\
(15.85 \pm 1.93)\end{array}$ & $\begin{array}{c}11.30-16.30 \\
(14.81 \pm 1.42)\end{array}$ & $\begin{array}{c}12.56-19.84 \\
(15.67 \pm 1.53)\end{array}$ & $\begin{array}{c}11.40-18.39 \\
(15.08 \pm 2.09)\end{array}$ & $\begin{array}{r}14.36-18.80 \\
(16.32 \pm 1.11)\end{array}$ \\
\hline OPW (\%HL) & $\begin{array}{c}15.67-21.47 \\
(19.61 \pm 1.59) \\
\end{array}$ & $\begin{array}{c}16.94-25.73 \\
(21.56 \pm 1.85) \\
\end{array}$ & $\begin{array}{c}20.04-25.13 \\
(22.16 \pm 1.06) \\
\end{array}$ & $\begin{array}{c}15.71-21.30 \\
(18.80 \pm 1.32) \\
\end{array}$ & $\begin{array}{c}17.33-23.34 \\
(19.92 \pm 1.39) \\
\end{array}$ \\
\hline OPDFD (\%SL) & $\begin{array}{c}4.62-6.74 \\
(5.48 \pm 0.53) \\
\end{array}$ & $\begin{array}{c}3.36-5.70 \\
(4.38 \pm 0.69) \\
\end{array}$ & $\begin{array}{c}5.61-7.74 \\
(6.55 \pm 0.57) \\
\end{array}$ & $\begin{array}{c}4.09-6.88 \\
(5.43 \pm 0.61) \\
\end{array}$ & $\begin{array}{c}3.67-8.13 \\
(5.91 \pm 1.48) \\
\end{array}$ \\
\hline PDL $(\% S L)$ & $\begin{array}{c}31.71-36.80 \\
(34.08 \pm 1.25) \\
\end{array}$ & $\begin{array}{c}28.91-35.65 \\
(32.60 \pm 1.43) \\
\end{array}$ & $\begin{array}{c}28.74-33.75 \\
(31.25 \pm 1.35) \\
\end{array}$ & $\begin{array}{c}30.79-36.91 \\
(34.10 \pm 1.460)\end{array}$ & $\begin{array}{c}30.21-36.06 \\
(32.99 \pm 1.82) \\
\end{array}$ \\
\hline DFL $(\% S L)$ & $\begin{array}{c}62.37-68.71 \\
(65.05 \pm 1.61)\end{array}$ & $\begin{array}{c}62.83-70.07 \\
(65.44 \pm 1.74)\end{array}$ & $\begin{array}{c}63.73-68.82 \\
(66.17 \pm 1.26)\end{array}$ & $\begin{array}{c}58.59-65.67 \\
(61.67 \pm 1.67)\end{array}$ & $\begin{array}{c}62.35-68.98 \\
(65.82 \pm 1.91)\end{array}$ \\
\hline PPEL $(\%$ SL) & $\begin{array}{c}17.17-22.68 \\
(19.90 \pm 1.07)\end{array}$ & $\begin{array}{c}17.71-21.33 \\
(20.06 \pm 0.82) \\
\end{array}$ & $\begin{array}{c}16.28-18.97 \\
(17.54 \pm 0.68)\end{array}$ & $\begin{array}{c}19.05-22.11 \\
(20.35 \pm 0.81) \\
\end{array}$ & $\begin{array}{r}16.43-20.00 \\
(18.42 \pm 0.85) \\
\end{array}$ \\
\hline PPL $(\% \mathrm{SL})$ & $\begin{array}{c}42.60-47.91 \\
(45.21 \pm 1.46)\end{array}$ & $\begin{array}{c}40.03-45.91 \\
(43.60 \pm 1.79)\end{array}$ & $\begin{array}{c}39.36-44.50 \\
(42.61 \pm 1.41)\end{array}$ & $\begin{array}{c}42.42-48.17 \\
(45.23 \pm 1.52)\end{array}$ & $\begin{array}{c}40.15-48.61 \\
(44.17 \pm 2.43)\end{array}$ \\
\hline $\operatorname{PAL}(\% \mathrm{SL})$ & $\begin{array}{c}50.45-56.87 \\
(53.86 \pm 1.57)\end{array}$ & $\begin{array}{c}48.61-56.91 \\
(53.80 \pm 2.11)\end{array}$ & $\begin{array}{c}49.84-55.56 \\
(53.44 \pm 1.80)\end{array}$ & $\begin{array}{c}51.11-56.50 \\
(53.99 \pm 1.55)\end{array}$ & $\begin{array}{c}50.00-59.88 \\
(54.02 \pm 2.47)\end{array}$ \\
\hline AFL $(\% S L)$ & $\begin{array}{c}41.50-46.71 \\
(43.50 \pm 1.47)\end{array}$ & $\begin{array}{c}40.00-46.58 \\
(42.94 \pm 1.99)\end{array}$ & $\begin{array}{c}40.85-46.89 \\
(43.55 \pm 1.75)\end{array}$ & $\begin{array}{c}38.40-45.40 \\
(41.31 \pm 1.95)\end{array}$ & $\begin{array}{c}39.80-46.85 \\
(42.84 \pm 2.10) \\
\end{array}$ \\
\hline MBD $(\% \mathrm{SL})$ & $\begin{array}{c}12.41-16.68 \\
(14.49 \pm 1.11)\end{array}$ & $\begin{array}{c}9.22-14.17 \\
(11.69 \pm 1.35)\end{array}$ & $\begin{array}{c}10.35-13.81 \\
(12.42 \pm 0.90)\end{array}$ & $\begin{array}{c}10.53-14.32 \\
(12.51 \pm 1.08)\end{array}$ & $\begin{array}{c}10.32-15.48 \\
(12.99 \pm 1.38)\end{array}$ \\
\hline CPD (\%SL) & $\begin{array}{c}6.24-8.97 \\
(7.43 \pm 0.55) \\
\end{array}$ & $\begin{array}{c}6.13-7.95 \\
(6.91 \pm 0.50) \\
\end{array}$ & $\begin{array}{c}5.67-7.24 \\
(6.44 \pm 0.41) \\
\end{array}$ & $\begin{array}{c}6.28-7.96 \\
(7.01 \pm 0.42) \\
\end{array}$ & $\begin{array}{c}5.76-9.18 \\
(7.20 \pm 1.06) \\
\end{array}$ \\
\hline PMTW (\%HL) & $\begin{array}{c}23.71-28.03 \\
(25.72 \pm 1.11) \\
\end{array}$ & $\begin{array}{c}22.20-28.59 \\
(25.61 \pm 1.54) \\
\end{array}$ & $\begin{array}{c}21.72-27.47 \\
(24.28 \pm 1.36)\end{array}$ & $\begin{array}{c}23.57-29.13 \\
(25.87 \pm 1.65) \\
\end{array}$ & $\begin{array}{c}23.86-28.89 \\
(26.01 \pm 1.29) \\
\end{array}$ \\
\hline VMTW (\%HL) & $\begin{array}{c}19.14-24.92 \\
(22.14 \pm 1.36)\end{array}$ & $\begin{array}{c}21.77-25.61 \\
(23.36 \pm 1.01) \\
\end{array}$ & $\begin{array}{c}17.49-24.22 \\
(21.34 \pm 1.22)\end{array}$ & $\begin{array}{c}20.68-25.48 \\
(22.26 \pm 1.37) \\
\end{array}$ & $\begin{array}{c}21.68-24.95 \\
(23.59 \pm 0.99) \\
\end{array}$ \\
\hline PMTL (\%HL) & $\begin{array}{c}3.08-5.29 \\
(4.11 \pm 0.48) \\
\end{array}$ & $\begin{array}{c}2.48-5.04 \\
(4.07 \pm 0.55) \\
\end{array}$ & $\begin{array}{c}3.76-6.01 \\
(4.69 \pm 0.53) \\
\end{array}$ & $\begin{array}{c}3.06-5.95 \\
(4.37 \pm 0.66) \\
\end{array}$ & $\begin{array}{c}3.34-4.95 \\
(4.15 \pm 0.44) \\
\end{array}$ \\
\hline VMTL (\%HL) & $\begin{array}{c}3.25-6.31 \\
(4.76 \pm 0.78) \\
\end{array}$ & $\begin{array}{c}3.55-7.12 \\
(4.65 \pm 0.87) \\
\end{array}$ & $\begin{array}{c}4.46-8.71 \\
(6.40 \pm 1.11) \\
\end{array}$ & $\begin{array}{c}3.33-5.41 \\
(4.06 \pm 0.57) \\
\end{array}$ & $\begin{array}{c}3.03-6.16 \\
(4.55 \pm 0.78) \\
\end{array}$ \\
\hline DFR & $61-76$ & $65-74$ & $63-71$ & $61-76$ & $60-76$ \\
\hline PEFR & $9-11$ & $9-11$ & $9-11$ & $9-11$ & $9-11$ \\
\hline PFR & $5-6$ & $5-6$ & $5-6$ & $5-6$ & $5-6$ \\
\hline AFR & $45-55$ & $48-56$ & $46-55$ & $45-55$ & $45-53$ \\
\hline
\end{tabular}


length) in the present study was presented in Figure 2. Scatter plots of the other Principal Component scores (not shown) showed less similar trends. Contributions of each morphometric characters to the second (PC2) and third (PC3) Principal Components (Principal Component coefficients) resulted from a PCA running on the fish samples for 20 morphometric characters were presented in Table 2.

A scatter plot of morphometric characters (Figure 2) showed that the scores of Dumbo, Paiton, Masamo, and Kenya strains were overlap, either based on the PC2 or PC3 axis. Those results suggested that morphometric characteristics of Dumbo, Paiton, Masamo, and Kenya strains were more or less similar. In other words, morphometric characteristics of those strains were not different from each other (indistinguishable). While, the scores of Egypt strain along PC2 axis separated from those of Paiton, Masamo, and Dumbo strains, and were only a little partly overlap with those of Kenya strain. Those results implied that morphometric characteristic of Egypt strain was only slightly similar with those of Kenya strain, and markedly differed from those of Paiton, Masamo, and Dumbo strains. Those differences were mainly defined by (Table 2, PC2 coeffi- cients in the decreasing order of importance) eye diameter, occipital process to dorsal fin distance, vomerine toothplate length, and the snout length (Table 1). Role of other morphometric characters were relatively low.

Results of the morphometric characterization in the present study revealed that, except for the Egypt strain, morphometric characteristics of Dumbo, Paiton, Masamo, and Kenya strains of the African catfish introduced to Indonesia were indistinguishable. Practically, it is imposible to differentiate those strains in the field based on their morphometric characteristics, since an exploration of the morphometric characters conducted in the present study revealed that there was no morphometric characters could be used as a diagnostic character enable to differentiate those strains. On the contrary, morphometric characteristic of the Egypt strain was more or less different than those of the other strains. These results corresponded to the results obtained from characterization on the interstrain morphometric variation of $C$. gariepinus from the African waters (Rognon et al., 1998; Teugels, 1998), which also suggested that Egypt strain was morphometrically different from the Lake Victoria, Senegal, and Swaziland strains, but was only partly overlap with Chad strain.

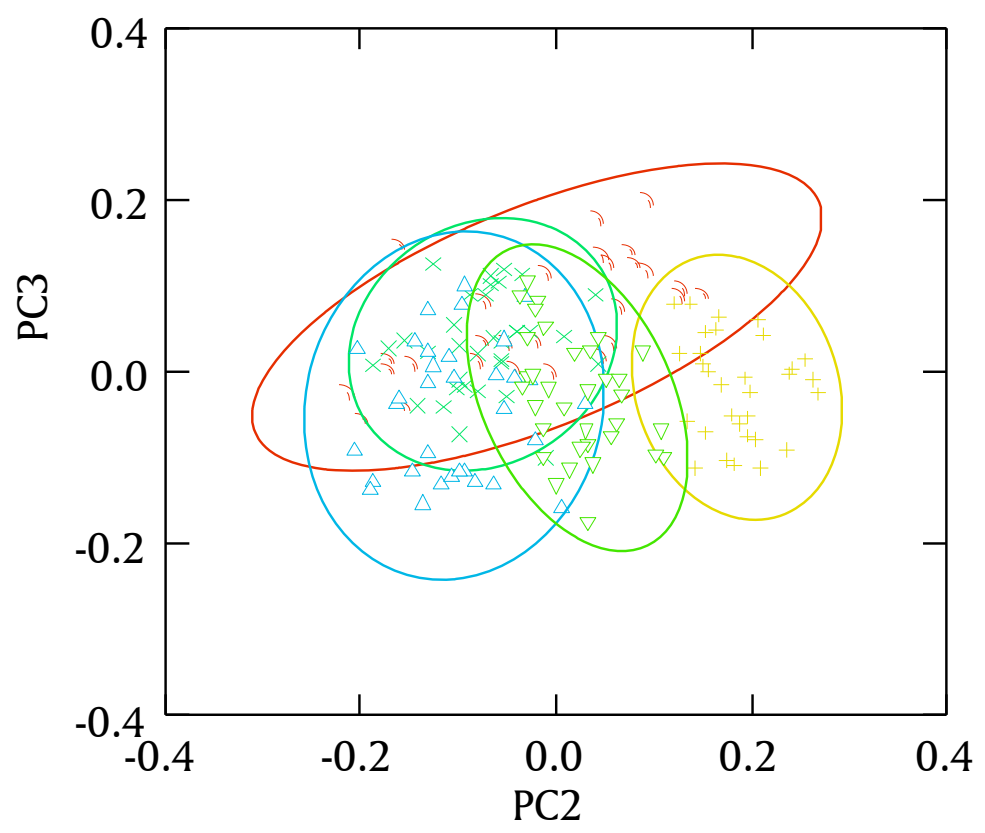

Figure 2. Scatter plot of the scores of Dumbo (1/2\%), Paiton (3\%), Egypt (+), Masamo $(\mathrm{x})$, and Kenya (i\%) strains of the African catfish Clarias gariepinus introduced to Indonesia along the axis of the second (PC2) and third (PC3) Principal Component resulted from a Principal Component Analysis (PCA) for the morphometric characters 
Table 2. Principal component coefficients of each morphometric character in the second (PC2) and third (PC3) Principal Component resulted from a Principal Component Analysis (PCA) performed on the samples of Dumbo, Paiton, Egypt, Masamo, and Kenya strains of the African catfish Clarias gariepinus introduced to Indonesia

\begin{tabular}{lcc}
\hline \multicolumn{1}{c}{ Morphometric characters } & PC2 & PC3 \\
\hline Head length (HL) & -0.2450 & 0.0389 \\
Head width (HW) & -0.1865 & 0.0332 \\
Snout length (SNL) & -0.4231 & 0.0956 \\
Interorbital width (IOW) & -0.0813 & 0.0213 \\
Eye diameter (ED) & -0.7447 & 0.2103 \\
Occipital process length (OPL) & -0.0941 & 0.1090 \\
Occipital process width (OPW) & -0.0331 & -0.0623 \\
Occipital process to dorsal fin distance (OPDFD) & 0.6523 & 0.4483 \\
Predorsal length (PDL) & -0.0435 & 0.1613 \\
Dorsal fin length (DFL) & 0.0482 & -0.033 \\
Prepectoral length (PPEL) & -0.2481 & 0.0311 \\
Prepelvic length (PPL) & -0.0001 & 0.1491 \\
Preanal length (PAL) & 0.0530 & 0.1223 \\
Anal fin length (AFL) & 0.0406 & -0.0979 \\
Maximum body depth at anus (MBD) & 0.1828 & 0.2091 \\
Caudal peduncle depth (CPD) & -0.2195 & -0.1696 \\
Premaxillary toothplate width (PMTW) & -0.3344 & -0.0165 \\
Vomerine toothplate width (VMTW) & -0.3275 & 0.0052 \\
Premaxillary toothplate length (PMTL) & -0.0023 & -0.1919 \\
Vomerine toothplate length (VMTL) & 0.4684 & -0.3875 \\
\hline
\end{tabular}

Based on the morphometric characterization in the present study, the African catfish strains introduced to Indonesia, except for Egypt strain, showed a little variation of the morphometric characteristics. Whether or not this implied the closely related of the strains could not be concluded, since there is no valid information on the exact origin of the strains introduced via Asian countries, except for Egypt, and Kenya strains as the strains introduced directly from Africa. Whereas, the results obtained from morphometric characterization of $C$. gariepinus from the African waters showing interstrain morphometric variation (Rognon et al., 1998; Teugels, 1998), as well as the results of a study on the interstrain morphometric characterization of $C$. gariepinus from the Turkish waters (Turan et al., 2005). The absence of interstrain morphometric variation in the introduced strains of African catfish in Indonesia, except for Egypt strain, compared to those of the wild strains in their natural habitats might reflected that genetic variation of Indonesian strains were lower than those of the wild strains. This information might be useful for the breeding program purposes of the species.

A scatterplot of fish sample scores of Dumbo, Paiton, Egypt, Masamo, and Kenya strains for four meristic characters between the axis of the first (PC1) and second (PC2) Principal Components was presented in Figure 3. Then, Principal Component coefficients for the meristic characters were presented in Table 3. In general, the scatterplot of meristic characters (Figure 3) showed that scores of Dumbo, Paiton, Egypt, Masamo, and Kenya strains were overlap, either based on the PC1 or PC2 axes. Those indicated that meristic characteristics of all strains of introduced African catfish were not different from each other. There is no meristic character could be used as a diagnostic character in differentiating the introduced strains of African catfish in Indonesia.

Since results of the present morphological characterization study of the African catfish strains introduced to Indonesia revealed that there is no morphological characteristics difference amongst them, except for Egypt strain, another characterization methods need to be further explored in order to evaluate its potency in differentiating those strains, mainly the molecular-genetic characterizations. Unfortunately, there was no information on the moleculargenetic study for all of those introduced African catfish strains, except for Dumbo (or Sangkuriang) and Paiton strains reported by Imron et al. (2011). Char- 


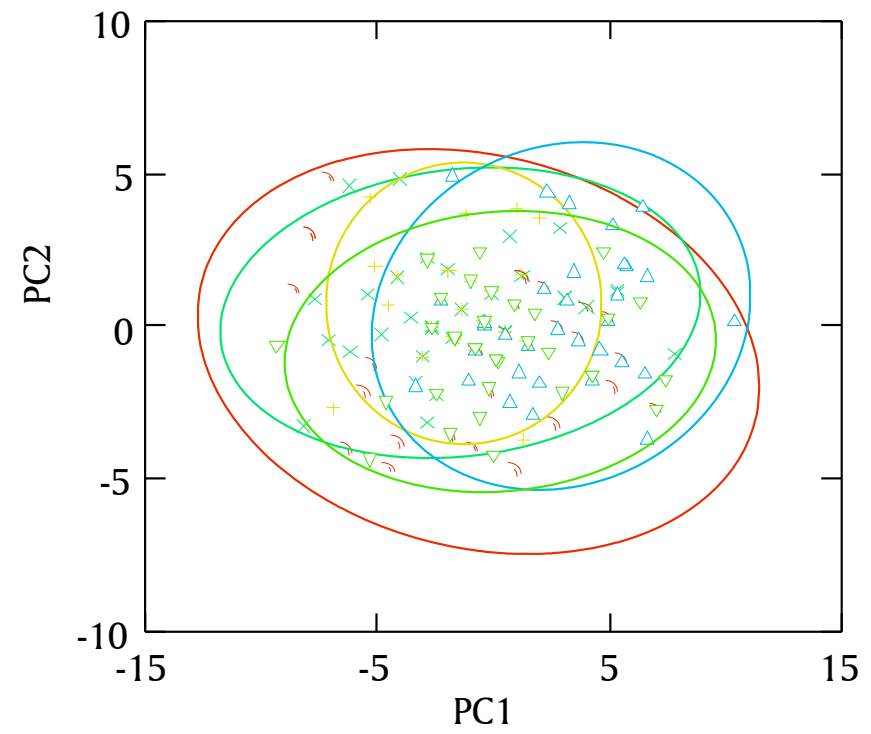

Figure 3. Scatter plot of the scores of Dumbo ( $\left.1 \frac{1}{2} \%\right)$, Paiton (3\%), Egypt (+), Masamo $(\mathrm{x})$, and Kenya (i\%) strains of the African catfish Clarias gariepinus introduced to Indonesia along the axis of the first (PC1) and second (PC2) Principal Component resulted from a Principal Component Analysis (PCA) for the meristic characters

Table 3. Principal Component coefficients of each meristic character in the first (PC1) and second (PC2) Principal Component resulted from a Principal Component Analysis (PCA) performed on the samples of Dumbo, Paiton, Egypt, Masamo, and Kenya strains of the African catfish Clarias gariepinus introduced to Indonesia

\begin{tabular}{lcc}
\hline \multicolumn{1}{c}{ Meristic characters } & PC1 & PC2 \\
\hline Dorsal fin rays number (DFR) & 0,9785 & $-0,2060$ \\
Pectoral fin rays number (PEFR) & 0,1359 & $-0,1330$ \\
Pelvic fin rays number (PFR) & 0,0025 & $-0,0883$ \\
Anal fin rays number (AFR) & 0,5855 & 0,8106 \\
\hline
\end{tabular}

acterizations of those strains using seven microsatellite markers suggested that Dumbo and Paiton strains were genetically different (Imron et al., 2011). Those revealed that although morphometric and meristic characteristics of Dumbo and Paiton strains were not different, however, they were genetically different. Thus, molecular-genetic characterizations of all (Dumbo, Paiton, Egypt, Masamo, and Kenya) strains were necessary to be carried out in order to fulfill their biological characteristics information. And, those would be the subjects of our forthcoming studies.

Another characterization and evaluation studies related to the aquaculture performances, e.g. growth, feed efficiency, disease resistance, reproductive performances and environmental tolerance (robustness) of those introduced African catfish strains in Indonesia were also necessary to be explored. Those all information would be beneficial in genetic management of those introduced strains, especially for the genetic improvement purposes. Those would be the subjects of our forthcoming studies.

For genetic management purposes in the future, the genetic purity of those introduced strains of the African catfish should be properly maintained. Genetic introgression should be avoided. Since the morphology characteristics of those strains were indistinguishable, except for the Egypt strain, and the lack of their molecular-genetic data, maintenance of their genetic purity could be firstly practiced through always keeping each of them in the well isolated places. Thus, uncontrolled interbreeding (crossbreeding) among 
them should be avoided.

\section{CONCLUSIONS}

Morphometric characteristics of Dumbo, Paiton, Masamo, and Kenya strains were indistinguishable, while morphometric characteristic of Egypt strain was more or less different than those of the other strains. Meristic characteristics of all introduced strains of the African catfish were not different from each other.

\section{ACKNOWLEDGEMENT}

Special thanks to Dr. Sudarto, an Indonesian Clarias catfish ichthyologist for supporting the references. Thanks to all researcher assistants of Clarias catfish team at the RIFB Sukamandi for their assisstances in preparing the fish specimens. Critical review supported by manuscript reviewer team of RIFB Sukamandi was also fully acknowledged.

\section{REFERENCES}

Anene, N.S., \& Gao, T.X. (2007). Is the Dutch domesticated strain of Clarias gariepinus (Burchell, 1822) a hybrid?. African Journal of Biotechnology, 6(8), 1072-1076.

Agnese, J.F., Teugels, G.G., Galbusera, P., Guyomard, R., \& Volckaert, F. (1997). Morphometric and genetic characterization of sympatric populations of Clarias gariepinus and C. anguillaris from Senegal. Journal of Fish Biology, 50, 1143-1157.

FishBase. (2014). Morphology data of Clarias gariepinus. Accessed on 1 Desember 2014 from: h t t p://fishbase.org/physiology/ MorphDataSummary.php?genusname = Clarias\&speciesname $=$ gariepinus\&autoctr $=1499$

Hanssens, M. (2009). A review of the Clarias species (Pisces; Siluriformes) from the Lower Congo and the Pool Malebo. Journal of Afrotropical Zoology, 5, 27-40.

Imron, Sunandar, D., \& Tahapari, E. (2011). Microsatellite genetic variation in cultured populations of African catfish (Clarias gariepinus) in Indonesia. Indonesian Aquaculture Journal, 6(1), 1-10.

Nurhidayat, M.A. (2000). Fluktuasi asimetri dan abnormalitas pada ikan lele dumbo (Clarias sp.) yang berasal dari tiga daerah sentra budidaya di Pulau Jawa. Master Thesis. Bogor Agricultural University. Bogor, $26 \mathrm{pp}$.

Pouyaud, L., Sudarto, \& Paradis, E. (2009). The phylogenetic structure of habitat shift and morphological convergence in Asian Clarias (Teleostei, Siluriformes: Clariidae). Journal of Zoological Systematics and Evolutionary Research, 47(4), 344-356.

Rognon, X., Teugels, G.G., Guyomard, R., Galbusera, P., Andriamanga, M., Volkcaert, F., \& Agnese, J.F.
(1998). Morphometric and allozyme variation in the African catfishes Clarias gariepinus and $C$. anguillaris. Journal of Fish Biology, 53, 192-207.

Skelton, P.H., \& Teugels, G.G. (1991). A review of the clariid catfishes (Siluroidei, Clariidae) occuring in southern Africa. Revista de Hydrobiologia Tropical, 24(3), 241-260.

Sudarto. (2003). Systematic revision and phylogenetic relationships among populations of Clariid species in Southeast Asia. Doctoral Dissertation. University of Indonesia. Depok, 263 pp.

Sunarma, A. (2004). Peningkatan produktivitas usaha lele Sangkuriang (Clarias sp.). Temu Unit Pelaksana Teknis (UPT) dan Temu Usaha Direktorat Jenderal Perikanan Budidaya, Departemen Kelautan dan Perikanan. Bandung, 4-7 Oktober 2004. 13 pp.

Teugels, G.G. (1986). A systematic revision of the African species of the genus Clarias (Pisces: Clariidae). Annales Musee Royal de l'Afrique Centrale, 247, 1-199.

Teugels, G.G. (1992). Clariidae. In Leveque, C., Paugy, D., \& Teugles, G.G. (Eds.). The Fresh and Brackish Water Fishes of West Africa Volume 2. ORSTOMMRAC. France, p. 468-495.

Teugels, G.G. (1998). Intra- and interspecific morphometric variation in Clarias gariepinus and $C$. anguillaris (Siluroidei, Clariidae). In Agnese, J.F. (Ed.). Genetics and Aquaculture in Africa. Actes du colloque Génétique et aquaculture en Afrique. Abidjan, $1^{\mathrm{er}}-4$ avril 1997. Institut Francais de Recherche Scientifique pour le Developpement en Cooperation. France, p. 241-248.

Teugels, G.G. (2003). Clarias lamottei (Silurifoems, Clariidae), a natural intergeneric hybrid from west Africa. Cybium, 27(1), 11-15.

Teugels, G.G., Adriaens, D., Devaere, S., \& Musschoot, T. (2007). Clariidae. In Stiassny, M.L.J., Teugels, G.G., \& Hopkins, C.D. (Eds.). The Fresh and Brackish Water Fishes of Lower Guinea, West-Central Africa Volume I. IRD-MNHN-MRAC. France, p. 653-691.

Teugels, G.G., Legendre, M., \& Hung, L.T. (1999a). Preliminary results on the morphological characterisation of natural population and cultured strains of Clarias species (Siluriformes, Clariidae) from Vietnam. In Legendre, M., \& Parisele, A. (Eds.). Proceeding of the Mid-Term Workshop of the Catfish Asia Project. The Biological Diversity and Aquaculture of Clariid and Pangasiid Catfishes in South-East Asia, 11-15 May 1998, Cantho, Vietnam, p. 27-30.

Teugels, G.G., Gustiano, R., Diego, R., Legendre, M., \& Sudarto. (1999b). Preliminary results on the morphological characterisation of natural population and cultured strains of Clarias species 
(Siluriformes, Clariidae) from Indonesia. In Legendre, M. \& Parisele, A. (Eds.). Proceeding of the Mid-Term Workshop of the Catfish Asia Project. The Biological Diversity and Aquaculture of Clariid and Pangasiid Catfishes in South-East Asia, 11-15 May 1998. Cantho, Vietnam, p. 31-36.

Turan, C., Yalcin, S., Turan, F., Okur, E., \& Akyurt, I. (2005). Morphometric comparisons of African catfish, Clarias gariepinus, in Turkey. Foolia Zoologica, 54(1-2), 165-172.
Wiecaszek, B., Krzykawski, S., Antoszek, A., Kosik, J., \& Serwotka, P. (2010). Morphometric characteristics of the juvenile of North African catfish Clarias gariepinus (Burchell, 1822) from the heated water aquaculture. Electronic Journal of Polish Agricultural Universities, 13(2). url: http:// www.ejpau.media.pl/volume13/issue2/art-02.html 
